\title{
SPECIFIC DEVELOPMENTS IN KIILI PLACE NAMES
}

Tiina Laansalu

Institute of the Estonian Language

\begin{abstract}
Place names have changed with the rest of the vocabulary during the development of the Estonian language. However, with place names characteristic developments have occurred that differ from the general vocabulary. Irregular shortening, group transition, folk etymology and adaptation have occurred. This article will give a brief review of each specific development and will give examples, based on the settlement names in Kiili.
\end{abstract}

Keywords: place names, settlement names, specific development, irregular shortening, group transition, adaptation, folk etymology

\section{Introduction}

When a place name develops, it gets a phonetic shape that at that time is relevant to the language. In time, the language will change and the vocabulary will change with it, as well as the place names. The founder of Estonian onomastics, Valdek Pall (1977: 37-38), has written that not all the phonetic changes in the common vocabulary are explainable by phonetic laws. There are changes that have broken the rules due to analogy, the relationship between stress and pace, or some other factors. However, regular development has played a significant role in phonetic development, although regular sound change has played a smaller part in place names than in other vocabulary. Place names have been more persistent (for example, there are names that still have the genitive's former marker $-n$ ). There have also been some changes that differ from the general vocabulary and are particularly characteristic to place names.

Specific development can be found only thanks to old documentation. A Danish scholar of onomastics, Vibeke Dalberg (2008: 86), states that even when a change is apparent, it can still 
be difficult to determine in what circumstances the change has happened, because in most cases no extra linguistic information is available. Valdek Pall (1977: 41) assumes that the most likely cause for specific development is a name's separation from its source, or the loss of connection between the proper noun and the common noun, as well as the goal of making the name more understandable to language users.

Studying the place names ${ }^{1,2}$ in the parish of Kiili, more than a few irregular changes were noticed. This article's aim is to give a brief review of the different groups of the changes.

\section{Irregular shortening}

A strong irregular shortening, which is much wider than in the general vocabulary, is distinctive to old place names. The shortening is particularly more likely to happen in secondary names, because the proper name is no longer related to a certain common noun. However, the shortening does not happen when the second component of the name has preserved the functions of a determinant (Pall 1977: 40-41).

The irregular changes are mostly noticeable in the second component of names with compound stems where, of the twoor three-syllable words, only a few phonemes often remain.

1 The material for the study comes from the place name archives of the Institute of the Estonian Language. The place names in the present domain of Kiili were collected in 1950, and from 1975 to 1981. There were a total of 566 settlement names, including separately identical names and parallel names. This material was compared with older documentation: the Danish Census Book ( $c a$ 1241), the early tax records (German Wackenbuch) from 1661 to 1685 , maps drawn in 1687 and 1697, plough-land revision documents from 1725 to 1726 (the inquisition of the parish of Jüri, where now Kiili is situated, took place in 1726), the revision lists (German Seelenlisten) from 1782, 1795, 1811, 1816, 1834, 1850 and 1858, the book of surnames in the parish of Jüri from 1835, and maps and plans from 1859 to 1875 . The recent data come from the author's Master's thesis "Settlement names of Kiili municipality" (Tärk 2010: 157-159).

2 There have been three manors in the Kiili region: Kurna, Sausti (also Suure-Sausti) and Nabala. 
However, the irregular shortening may also occur in the first component in compound names and in elliptical names (Pall 1977: 38). In the case of the names in Kiili, the shortening has occurred mostly in the second component of names with compound stems, and the shortening of the first components is not that common.

In the following, some examples of the irregular shortenings of settlement names in Kiili are presented. The name shapes used during the name gathering are underlined and (the supposed) shortened clusters are written in bold; the shortened part of the name and its assumed source are presented separately. To the farm names are added the villages they were situated in according to the informants, and then the type of place. In addition, the earliest documents are enumerated (the same name shapes are not repeated, only the relevant year is given), the counterparts of personal names and common nouns and some detailed information are given if necessary, and finally toponymical comparison material ${ }^{3}$ is added.

$\underline{\text { Alta }}<$ Alttoa; $-(t) a<-$ toa. (Lähtse, f.) 1834 Altoa, 1835 Alltoa, 1850, 1858 Alta. < alt 'being below something' + tuba (elumaja 'dwelling house'). The shortened name shape's geminated $t$ probably belongs to the first component, as well as the ending formed from the shortened second component (cf. Kettunen 1955: 439 Alttoa, 228 -ta <-toa, Pall 1969: 21 Alttoa, Kallasmaa 2010: 30 Alttoa).

$\underline{\text { Harjuva }}<$ Harjuoja; -va $<-o j a$. (Kurna-Mõisaküla, f.) 1697 Harioija Krogs 'tavern', 1782, 1795 Harjooja Hans, 1811 Arjowa Rein, 1816 Arjowa, 1834 Orjawa, 1835 Arjowa, 1850, 1858 Orjawa, 1859 Krug 'tavern' Arjowa, 1873 Harjowa. < fn. Harju Harjo Mägiste 1929: 24 or a cog. (from Harju) + oja 'creek'. The farm probably got its name from a nearby creek (in the map of 1697, the Harjooja creek was near the Harioija taverns, which later became a farm); now there is a Harjava main

3 The name material was compared with Kettunen (1955), Pall (1969), Simm (1973), and Kallasmaa (1996 and 2010). Identical names from the sources of comparison have not been repeated, but page numbers are given, and similar name shapes are also given. 
trench in that region (cf. Pall 1969: 27 Harju, Simm 1973: 27 Harju, Kallasmaa 1996: 29 Harju, Kallasmaa 2010: 36 Harju).

Ihure $<$ Ihuvere; -re <-vere. (Kurna-Mõisaküla, f.) 1697 Ihoffer, 1726 Hisofer Matz, 1782 Ihowere Hans, 1795 Ihowerre Hans, 1811 Ihowerre Carl, 1816 Iowerri Mart, 1834 Ihowerre Marti, 1835, 1850, 1858 Ihhowerre, 1875 Ihowerre. < fn. Iha $(* I h o i)+$ formant -vere. Current language users may interpret the toponym Ihuvere as something anatomical (ihu 'flesh', vere 'gen. blood') or something related to grinding (ihuma 'to grind, to sharpen'), more creative people may even relate it to Christianity, where ihu 'flesh' and veri 'blood' have their own specific meaning. Actually, Ihuvere is a very old name and its components are certainly older than Christianity in Estonia. The Finnish scholar of onomastics Päivi Rintala (2008) writes that the underlying stem iha probably occurred in some regions of Balto-Finnic languages as a personal name and from early on, when they were in close contact, people started using it as a name stem. According to Rintala, Estonian place names with the modifier $i h u$ can be compared to the modifier iha, because they have probably derived from it. In Rintala's opinion, the farm name Ihuvere in the parish of Jüri is a clear example of an anthroponymical source (Rintala 2008: 314; cf. Kettunen 1955: 293, Kallasmaa 1996: 41 Ihumetsa.)

$\underline{\text { Kurna }}(\underline{\text { Kurna })}<*$ Koiranoja; $-n a<$ gen. marker $-n+-o j a$; Kur- < koera. (m., v.) 1241 Queronoice, 1384 Koiranea, Koironia, 1388 Koyronia, 1468 Karnall, 1475 Coirnal, ca 1500 Korenoya, 1535 Kornal, 1586 Kornall, 1589 Cornall, 1639 Kornall, 1663 Cornal, 1671 Kornall, 1732 Kurna, 1782 Curnal, 1840 Cournal (Johansen 1933: 559). 1687 Kornal, 1726 Cournall, 1782 Cournal, 1795, 1811, 1816 Cournall, 1834, 1835, 1850, 1858 Cournal. < koer 'dog' + oja 'creek'. This is a native village name 4 that is presumably second-

4 The Kurna manor was built at the site of the native village. The first written documents regarding the manor are from 1384, when it belonged to the Treydens. In 1670 Otto Wilhelm von Fersen took possession of it. After the Great Northern War, it belonged successively to the von Wrangells, von Schlippenbachs, von Derfeldens and von Lantingshausens. In 1833 the manor was inherited by Helene von Knorring, to whom it belonged until the end of the 19th century. (Särg 2006: 93-94) 
ary to the hydronym. According to Lauri Kettunen (1955: 138), the dialectal koer $>$ kuer changes in the compound's attribute Koir- > Kur-. The name probably changed Koiranoja $>$ Kuernjan (a village) $>$ Kurna (a village); $j$ is here pronounced so softly that the $n$ does not palatalize (cf. Kettunen 1955: 137-138, Kallasmaa 1996: 137).

Manni $($ Manni $)<*$ Maande $<*$ Maantee; $-n i<$ gen. marker - $n+$-tee; Ma- < Maa-. (Lähtse, f.) 1665 Manndi Martt, 1666 Mande Martt, 1667 Manndi Martt, 1668 Mande Martt, 1679 Mando Mart, 1680 Manda Mart, 1684, 1685 Manda Mart Krüger 'innkeeper', 1687 Manni Krog 'tavern', 1726 Manni Jack, 1782 Juhan Maniffer Krüger 'innkeeper', 1811 Manni Körtso Hans, 1816 Manni Hans, 1835, 1850 Manni Krug 'tavern'. < maa 'land' + tee 'road, path'. The name shape Maniffer probably shows how the formant -vere has been transferred as a template to other names as well (cf. 1697 Ihoffer, 1782 Kurrefer). In the case of Manni, the formant has not become established. Perhaps it was used only by the one who wrote down the names and it had never been in active use. Older documentation leads us to assume that the name originates from the common noun maantee 'highway, high road'. This seems quite valid, because the taverns were situated by high roads. However, it still could have originated from a personal name, cf. Mant : Mandu Mando (Mägiste 1929: 36; cf. Kallasmaa 1996: 205, Kallasmaa 2010: 143).

Metsari < *Metsaääre; -ri < ?ääre. (Metsanurga I, f.) 1661, 1662 Metzere Matzs, 1663 Metzerre Matzs, 1665 Metzssere Matzs, 1666, 1667, 1668 Metzere Matzs, 1680 Metzer Matz, 1684, 1685 Metzere Matz, 1687 Metzara Mattz, 1726 Metzara Rein, 1782 Metsare Matz, 1811 Metsare Mats, 1816 Metsari Matz, 1834 Metzarri, 1835 Metsarri, 1850 Metzari. < ? mets 'forest' + äär 'side'. Older documents (1661, 1662 Metzere Matzs, 1782 Metsare Matz, and 1811 Metsare Mats) lead us to assume that the second component could have been the common noun $\ddot{a} a r$ 'side'. However, cf. 1687 Metzara Mattz, and 1726 Metzara Rein show that it is possible that the name originates from the common nouns mets 'forest' + aru 'dry upland meadow'. Cf. Kallasmaa 1996: 215, where Metsara < mets 'forest' + aru 'dry upland meadow' (in older documents: 1738 Metzarro, 1756 Metsare; cf. 
Kettunen 1955: 320, Pall 1969: 140 Metsara, Kallasmaa 1996: 215 Metsara, Kallasmaa 2010: 149 Metsaru laasma.)

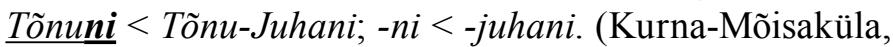
f.) 1782 Tonno Juhani Mart, 1795 Toenno Juhani Mart, 1811 Tönno Johann̈̈ Michel, 1816 Tonno Johann, 1834 Toenno Johann, 1835 Toenno Juhhani, 1850, 1858 Tönno Juhanni, 1875 Tönnojani. $<$ fn. Tõnu + fn. Juhan. At the time of the name gathering, the shorter version was used, as well as the probably folk etymologically derived official name shape Tõnu-Jaani. Cf. Kettunen 1955: 152 -ni<-Jaani (cf. Pall 1969: 250 Tõnu-Jaani).

Väljari $<$ Välja-Jüri; -ri < -jüri. (Paekna, f.) 1667, 1668 Wellÿa Jurg, 1679, 1680 Welÿa Jürgenn, 1684, 1685 Welÿa Jürgen, 1687 Wallia Jürgen, 1726 Welja Jürri Mart, 1782 Welja Jurri, 1782 Welja Jurrü Jahn, 1811 Wäljari Jahn, 1816 Wäliari Jahn, 1834, 1835 Wäljari, 1850 Weljari. < cog. Välja 'gen. field' + fn. Jüri. Cf. Kettunen 1955: 520 Väljari, Pall 1969: 283 Väljari.

In the underlined name shapes, it is clear that in some cases, during the time of the gathering, both the short form and the form before the shortening were used. The documentation of the names made the on-going shortening more difficult. The shortening was natural in the spoken language but now the official name shape ${ }^{5}$ retains the use of the longer shape as it is considered to be more correct, and so it is impossible for the shortened name shape to become the unique form.

\section{Group transition}

One of the influences on place name phonetics has been the transition of one group to another. This is a phenomenon occurring in place names when parts of a name with similar phonetic shape can substitute for each other during variation. In the case of farm names in Kiili, the alternation has occurred

5 When both the shortened place name and the name shape before the shortening were used at the time of the name gathering, the unshortened name shape was more likely to become official, e.g. Alttoa (pro Alta), Ihuvere (pro Ihure) and Väljajüri (pro Väljari). 
with -mäe 'gen. hill' and -maa 'land' (mostly in the direction -mäe >-maa). According to Valdek Pall (1977: 41), this is probably a group change, where in certain cases it could have been affected by the vowel harmony. The cause could also have been the loss of connection with the common noun, in which case the postpositive component -mäe did not carry the determinant's semantics, being now a part of the settlement name, where - maa actually fits better anyway. The endings -mäe and $-m a(a)$ often vary in place names and it is not always possible to determine the original form. Also, based on the names in Kiili, the endings -aia 'gen. garden' and -oja 'creek', as well as -selja 'gen. ridge (geo.)' and -silla 'gen. bridge' often vary (it is possible that the latter was also caused by the assimilation $l j>l^{\prime} l$ distinctive to the central dialect, although the same phenomenon has been described in place names in Saaremaa and Põhja-Tartumaa). Next some examples of group transition in farm names in Kiili.

Allikmäe Allikmaa. (Sookaera, f.) 1661 Hallikmah Jak, 1662, 1663, 1665 Hallikma Jak, 1666 Hallikmeh Jak, 1667 Hallikoma Jak, 1668 Hallikma Jak, 1679 Halligmäh Jaacke, 1680 Halligkmah Jaack, 1684, 1685 Halligkmah Jack, 1687 Hallikmeh Jak, 1726 Allickmeh Thomas, 1811, 1816 Hallikmäe Hans, 1834, 1835, 1850 Allikma. < allikas '(water) spring' or the fn. Hallik+ -mäe 'hill'. As we can see, in these documented name shapes the name endings -mäe and $-m a(a)$ varied even hundreds of years ago and due to that it is impossible to determine the original form. Supposedly, the unshortened name shape began to be used again when the farm names were made official (cf. Pall 1969: 18 Allika (Allikamäe farm, Allikmäe hill), Kallasmaa 1996: 20 Allika (Allikamaa), Allikamäe.)

Aruaia $\sim$ Aruoja. (Metsanurga I, f.) (cf. Simm 1973: 28 Aruaia.) The similar aia (aja) oja alternation also occurred in Saaremaa: Arbaia, 1798 Arbuoja (Kallasmaa 1996: 27) and Vabuaia, 1811 Wabbooja Hindrik (Kallasmaa 1996: 472), and in Hiiumaa: Remliaia Remleoja (Kallasmaa 2010: 209).

Eerumäe Eerumaa. (Lähtse, f.) 1795 Semon Geremeof, 1811 Ivan Semenov, 1816 Peter Semenow, 1834 Geroma, 
1835 Gerome, 1850 Eroma, 1858 Eromae. $<$ fn. Jeremei and the colloquial Jerjoma Superanskaja 2006: 183. Name forms with compound stems are folk etymological developments from the simple form Eruma, originating from a first name ( cf. Kettunen 1955: 184 Jeru, Kallasmaa 1996: 35 Eeru.)

Kirjasselja $\sim$ Kirjassilla. (Kurna-Mõisaküla, f.) 1873 Kirjasilla, 1875 Kirjasilla. Documents lead us to assume that the source was the common noun kiri or kirju 'many-coloured, mottled, dappled' (cf. kirjas 'mottled cow') + sild 'bridge'. Variating of -selja and -silla has also been noticed in western dialectal place names by Marja Kallasmaa (2003: 66-67, e.g. Lehtsel'la einamaa $\sim$ Lehtsilla einamaa and Kuresel'lamägi $\sim$ Kuressilla$m a ̈ g i)$. This possibility has also been mentioned by Valdek Pall (1967: 98). According to Kallasmaa (2000: 109), the determinant -selja can be found in meadow and rangeland names and other nature names, the source being selg : selja 'geo. ridge'.

Põldmäe Põldmaa. (Nabala-Nõmmeküla, f.) 1850 Pöld$m a$. It is possible that the name written in the revision list is a short variant of the name Põldmäe, especially since it was also later used as Põldmäe, which later on was shortened to Põldme. However, it can't be ruled out that the original name shape could have been Põldmaa. (cf. Pall 1969: 192 Põldmaa, Kallasmaa 1996: 308 Põldemägi, Põldmaa, 2010: 196 Põldmäe Põldma).

\section{Folk etymology and adaptation}

The next type of specific development that is reviewed is folk etymology ${ }^{6}$. Folk etymology is not a result of phonetic changes in common vocabulary, but is due to the language

6 Vibeke Dalberg (2008: 83) states that folk etymology is not a very exact term because, in her opinion, the phenomenon should be seen as a functional development, not as an etymological development. Language users are prone to decode what they hear based on their linguistic norms, which is why an incomprehensible name is adapted to the norm (although this is unconscious) and its shape is changed slightly so the meaning will become more understandable. 
user's linguistic intuition. The first thing that brings out folk etymology is often the fact that the common nouns that form a name have disappeared from the general language, although even the names that could be folk etymologized can change in different ways from their equivalent common noun. Folk etymology involves a reinterpretation of a name (although Vibeke Dalberg states that it is difficult to judge whether the reinterpretation came before the form change or vice versa; both factors may occur at the same time). Dalberg also remarks that names affected by folk etymology are quite often compound names. She proposes that this leads to another latent cause of changes. Namely, the language user assumes that the compound names are formed from existing words and often interprets the name according to the "living vocabulary". So, the folk etymologically derived name shapes often have compound stems (Dalberg 2008: 81-83, 90).

Valdek Pall has also described folk etymology as an attempt to make the name more understandable for the user, being the opposite of the shortening of the name components and group transition. For this reason, sometimes a word that is not actively used is replaced with something more familiar (Pall 1977: 41).

Marja Kallasmaa (1995: 764-766) believes that folk etymology has played a much greater role in Estonian farm names than is commonly believed. This is because the detection of folk etymological changes can often be very difficult, due to the fact that, when a name is semantically reconstructed in a folk etymological way, it will behave in a new way - it will behave like the word or word combination that it now consists of. As folk etymology can only be found by looking from another angle of time, specific developments can be detected only if there are some old documents.

A mechanism similar to folk etymology is name adaptation. Place names of foreign origin are often adapted to the language's phonetic structure, as when common nouns are borrowed (Pall 1977: 42). In the case of settlement names in Kiili, mainly names of foreign origin have been adapted - mostly from 
the Russian first names of the farmers of the former Veneküla ${ }^{7}$, but also from the surnames of German manorial estate owners. In some names both folk etymological changes and adaptation can be found.

Next, some examples of folk etymology and adaptation in the settlement names in Kiili (name shapes that were used during the name gathering are underlined).

Andrese < Russian fn. Andrei. (Lähtse, f.) 1795, 1811, 1816 Andrë Isakow, 1834 Adresse, 1835 Andressi, 1850, 1858 Andresse. < Russian fn. Andrei Rajandi 1966: 25. The name has been adapted to Estonian, cf. Estonian fn. Andres : Andrese Mägiste 1929: 22, Andreas Andre(u)s Rajandi 1966: 25 (cf. Pall 1969: 23 Andrese, Simm 1973: 26 Andrese, Kallasmaa 1996: 22 Andrese, Kallasmaa 2010: 31 Andrese).

Eerumaa $<\underline{\text { Eruma }}<\underline{\text { Jeruma }}<$ Geroma $<$ Russian fn. Jeremei. (Lähtse, f.) 1795 Semon Geremeof, 1811 Ivan Semenov, 1816 Peter Semenow, 1834 Geroma, 1835 Gerome, 1850 Eroma, 1858 Eromae. $<$ Russian fn. Jeremei and the colloquial Jerjoma Superanskaja 2006: 183. The name has been adapted to Estonian, cf. Estonian fn. Eero Eeru (Mägiste 1929: 23), Eero Eeru $<\operatorname{Eric}(h) \sim \operatorname{Erik}$ (Rajandi 1966: 57). The reason for the development of the compound name Eerumaa could be folk etymology, where the name users have changed the foreign Eruma into something more suitable for their language comprehension - a compound name consisting of the first name Eeru and the generic term maa 'land' (cf. Kettunen 1955: 184 Jeru, Kallasmaa 1996: 35 Eeru).

Kaarepere < German sn. Scharenberg. (m.) 1732 Kareberre, 1840 Kareperre (Johansen 1933: 596-597). Cf. Nabalas 1668 Sara Karber Hans, 1679 Kahriber Hansen Wittibe 'wid-

7 After the Great Northern War, the Tsardom of Russia brought its army equipment to the land of the Sausti manor. When the troops were disbanded, a lot of the soldiers stayed at the Sausti manor as peasants. In the revision list of 1726, there are no peasants with Russian names, but in the following ones (1782 and 1795) there is documentation of more than a dozen Russian names. This is how the place name Veneküla 'Russian village' was established. The name was official until 1977. In older documents, Veneküla was included in the village of Lähtse as a village part. 
ow', 1680 Kahriber Hannss Witbe 'widow', 1684, 1685 Karreber Witbe 'widow' and 1680 Kahriber Bertel, 1684, 1685 Karreber Bertell. < German sn. Scharenberg Johansen 1933: 295. Cf. Kettunen 1955: 161, 219, 299. Kaarepere was the parallel name for the Sausti manor ${ }^{8}$. The name of the Kaarepere manor came from the manorial estate owner's German surname Scharenberg. Matthias Johann Eisen (1924: 75) writes that, at the time of Anton Thor-Helle, Estonians called the Sausti manor Kaarepere. Koidu Uustalu (1968: 743) also examines the development of the toponym Kaarepere and writes more specifically about the name Kaarepere in the parish of Palamuse. The former Kaarepere manor was situated there and it got its name from B. Scharenberg, to whom the manor belonged beginning in 1601. Estonians started to call it the Kaarepere manor. In Middle Low German orthography, the sch sound at the beginning of the word marked the consonant cluster $s k$ and that explains the $k$ at the beginning of Kaarepere. The second component of the surname is -berg and this has been replaced by the Estonian word -pere 'family' (cf. Pall 1969: 45-46, Kallasmaa 2010: 60 Kaarpere).

Maksima $<$ Russian fn. Maksim. (Lähtse, f.) 1782 Maxim Karpoff, 1795 Maxim Karpof, 1811 Maxim Karpow, 1816 Iwan Maximow, 1834, 1835, 1850, 1858 Maxima. < Russian fn. Maksim < Maximilianus Rajandi 1966: 120. In addition to adaptation, this is an interesting example of a contemporary group transition. In Kiili, Maksimäe Street got its name from a farm name and a new residential area called Maksima has been built there. But the association representing the residential area took the name Maksimaa for legal reasons (Maksima and Maxima were already, respectively, the name of a detailed plan and a grocery store chain in the area). The street name Maksimäe is prob-

8 The Sausti manor $(\operatorname{Sau} \beta)$ was first mentioned in 1453 . It belonged to the noble von Scharenberg family for about three hundred years. The manor also had a cattle manor: Padiküla (Paddiküll). In 1782 the Sausti manor came into the possession of the Tiesenhausens. (Särg 2006: 185, 188) When in the 17th century the Saue manor, which was called VäikeSausti 'Small-Sausti', was separated from the Sausti manor, the old manor started to be called Suure-Sausti $(\operatorname{Gro} \beta$ Sau $\beta)$ 'Big-Sausti'. 
ably also connected to Maksima Hill, which was close to the Maksima farm (the hill got its name from the farm name, so it is a secondary name; the former name was Kiiliaru Hill) (cf. Kettunen 1955: 126, Simm 1973: 67 Maksa, Kallasmaa 1996: 204 Maksimi).

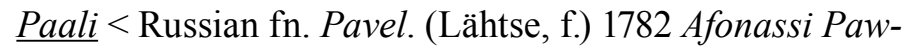
low, 1795 Afanasse Pawlaw, 1834 Pali, 1835 Pali, 1850 Pahly, 1858 Pahly. < Russian fn. Pavel Superanskaja 2006: 263, cf. Paavel, -i Mägiste 1929: 42, Paavel (Rajandi 1966: 142; cf. Kettunen 1955: 102, 293, Pall 1969: 169, Simm 1973: 80, Kallasmaa 1996: 267, Kallasmaa 2010: 176).

Penduska $<$ Russian fn. Pentelei. (Lähtse, f.) 1795 Pentiley Antonoff, 1811 Pentilei Antonow, 1816 Penteley Antonow, 1850 Pentuska. < Russian fn. Pentelei (Superanskaja 2006: 270; cf. Kettunen 1955: 126 Pentuska).

$\underline{\text { Raudalu }}<$ Raudaru. (v.) See in the plans of the Kurna manor in 1875 Rautal mets 'forest', Rautallo mets 'forest', Rautallo soo 'swamp' (a rangeland). In addition, the name has occurred as a cognomen in the village Saire: 1782 Neu Raudarro Hans, 1795 Neu Raudaro Hans, 1811 Raudalo Jurrÿ; 1782 Alt Raudarro Tönno, 1795 Alt Raudaro Toenno. Lauri Kettunen proposes that the source could be Raua talu 'farm' (1955: 110111). It seems more likely that it comes from the common names raud 'iron' + aru 'dry upland meadow', where a change has occurred for phonetic reasons aru > alu (an example of the same phenomenon is the adaptation of loan words, e.g. German der Reiter > rüütel 'knight' and der Räuber > röövel 'robber') (cf. Kallasmaa 1996: 332 Raua).

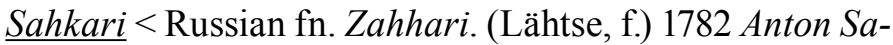
charoff, 1795 Anton Sacharof, 1811 Anton Sacharov, 1816 Peter

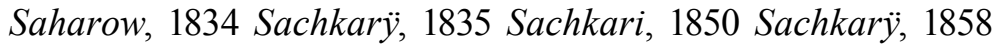
Sachkari. < Russian fn. Zahhari Superanskaja 2006: 188, cf. fn. Sagarjas, Sahar, Sahkarjas, Sahker, Sakaria(s) < Sacharias Zacharias Rajandi 1966: 151 (cf. Simm 1973: 102 Sahhari).

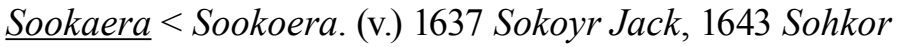
Lauer, 1687 Sockor, 1744 Sockar, 1765, 1871 Sokoira. The former name ?*Raadu - 1241 Ratho, 1493 Rade, 1495 Radt, Rath, 1510 
Rath, 1565 Rawo, 1586 Rahdo, Rade (Johansen 1933: 569). 1726 Sookar, 1782 Sokoir, 1811, 1816, 1834, 1835, 1850, 1858 Sokare. < soo 'swamp' + koer 'dog'. Nowadays this is interpreted as a name consisting of the words soo 'swamp' and kaer 'oat', but older documents (1637 Sokoyr Jack, 1643 Sohkor Lauer, and 1765,1871 Sokoira) show that the name actually comes from the word koer 'dog'. The name has probably changed due to folk etymology. The village might have developed from a group of isolated farms (German Streugesinde); in 1661 these farms resp. farmers were documented: Sohkohr Laur and Sohkohr Cäsper, and in 1679 a third one: Sohkur Jaecke. According to Lauri Kettunen, the village name Ratho, which is recorded in the Danish Census Book, originates from raaduskane, raaduskas, which means 'poor, raddled' (documented in coastal dialect). Kettunen finishes with a question: does sookoer 'swamp dog' also mean something poor and raddled? (1955: 173-174).

$\underline{\text { Treja }}<$ German sn. Treyden. $(\mathrm{m})<.\mathrm{sn}$. Treyden (Johansen 1933: 295). This is the parallel name for the Kurna manor in popular language. Until 1670 the manorial estate belonged to the Treydens. Cf. the Reina manor in the parish of Pöide - Reina < sn. Treyden (Eisen 1924: 68).

\section{Concluding remarks}

All types of specific developments can be found in Kiili place names: irregular shortenings, group transition, folk etymology and different adaptations. Specific developments that have occurred in place names can only be detected and proved if there is previous documentation; otherwise this is only speculation.

Language development will continue and a lot of place names will evolve with it. We do not always know exactly where place names come from and only time will tell where they are heading. 


\title{
Address:
}

Tiina Laansalu

Institute of the Estonian Language

Roosikrantsi 6

10119 Tallinn

E-mail: Tiina.Laansalu@eki.ee

\author{
Abbreviations \\ cog. - cognomen \\ f. - farm \\ fn. - first name \\ gen. - genitive \\ geo. - geographical \\ m. - manor \\ sn. - surname \\ v. - village
}

\section{References}

Dalberg, Vibeke (2008) Name and place: ten essays on the dynamics of placenames. Gillian Fellows-Jensen, Peder Gammeltoft, Bent Jørgensen, and Berit Sandnes, eds. København: Københavns Universitet.

Eisen, Matthias Johann (1924) "Eesti keelest kadunud, saksa keeles püsinud eestikeelsed kohanimed". Eesti Keel 3-4, 67-82.

Johansen, Paul (1933) Die Estlandliste des Liber Census Daniae. Kopenhagen-Reval.

Kallasmaa, Marja (1995) "Rahvaetümoloogia ja historismi printsiip onomastikas". Keel ja Kirjandus 11, 763-766.

Kallasmaa, Marja (1996) Saaremaa kohanimed 1. Helmi Neetar, ed. Tallinn: Eesti Keele Instituut.

Kallasmaa, Marja (2000) Saaremaa kohanimed 2. Tiina Lias, ed. Tallinn: Eesti Keele Instituut.

Kallasmaa, Marja (2003) Läänemurde loodus- ja viljelusnimed. Tallinn: Eesti Keele Sihtasutus.

Kettunen, Lauri (1955) Etymologische Untersuchung über estnische Ortsnamen. Helsinki: Suomalainen Tiedeakatemia.

Mägiste, Julius (1929) Eestipäraseid isikunimesid. Tartu: Akadeemilise Emakeele Seltsi kirjastus. 
Pall, Valdek (1967) "Liittüvelisi kohanimesid”. Keel ja Kirjandus 2, 95-98.

Pall, Valdek (1969) Põhja-Tartumaa kohanimed 1. Madis Norvik, ed. Tallinn: Valgus.

Pall, Valdek (1977) Põhja-Tartumaa kohanimed 2. Madis Norvik, ed. Tallinn: Valgus.

Rajandi, Edgar (1966) Raamat nimedest. Tallinn: Eesti Raamat.

Rintala, Päivi (2008) Ihalasta Ihaviljankorpeen. Iha-vartalo Suomen henkilön-ja paikannimissä. Helsinki: Suomalaisen Kirjallisuuden Seura.

Simm, Jaak (1973) Võnnu kihelkonna asustusalane toponüümika. Manuscript in the Institute of the Estonian Language, Tallinn.

Superanskaja, Aleksandra Vasil'evna (2006) Slovar' russkix ličnyx imën. Moska: Èksmo.

Särg, Alo (2006) Harjumaa mõisad ja mõisnikud. Tallinn.

Tärk, Tiina (2010) Kiili valla asustusnimed. Unpublised Master's Thesis. Tartu: Tartu Ülikooli eesti ja üldkeeleteaduse instituut. Available online at $<$ http://dspace.utlib.ee/dspace/bitstream/10062/15080/1/ tark_tiina.pdf $>$. Accessed on 01.05.2012.

Uustalu, Koidu (1968) "Mõisate ja mõisnike nimedest lähtunud kohanimesid Lõuna-Eestis”. Keel ja Kirjandus 12, 734-746.

Kokkuvõte. Tiina Laansalu: Eriarengud Kiili kohanimedes. Kohanimed on keele arenedes muutunud üheskoos muu sõnavaraga, samas on kohanimedes lisaks aset leidnud omapäraseid, üldsõnavarast erinevaid arenguid. Nendeks on ebareeglipärane lühenemine, sarjasiirdumine, rahvaetümoloogia ja mugandumine. Artikkel tutvustab põgusalt igat eriarengurühma ning esitab nende kohta näiteid Kiili asustusnimede põhjal.

Märksõnad: kohanimed, asustusnimed, eriarengud, ebareeglipärane lühenemine, sarjasiirdumine, rahvaetümoloogia, mugandumine 
